Language in Africa 1(3), 2020, 292-335. doi: 10.37892/2686-8946-2020-1-3-292-335

\title{
PERSONAL PRONOUNS IN BUA LANGUAGES
}

\author{
Pascal Boyeldieu \\ CNRS, UMR 8135 Langage, Langues et Cultures d'Afrique \\ pascal.boyeldieu@cnrs.fr
}

\begin{abstract}
Bua languages in general are poorly documented and many aspects of their morphosyntax are still undescribed. The purpose of this paper is to outline a state of the art concerning the structure and operation of the personal pronoun systems. Largely based on unpublished or restricted documentation, it systematically reviews the systems of eight languages, commenting on both the identity of persons and the types of functional paradigms. Despite numerous shortcomings and uncertainties, interesting observations can be made concerning the $1^{\text {st }}$ person plural 'exclusive'/'inclusive' contrast, the logophoric pronouns, the tonal polarity of Subject and Object pronouns, and different types of personal possessive constructions.
\end{abstract}

Key words: personal pronouns, $1^{\text {st }} \mathrm{pl}$. exclusive/inclusive, logophoric, reflexive, same referent, tonal polarity, possessive construction, Bua languages, Adamawa languages

\section{Introduction}

The Bua languages are spoken by small communities living in southern Chad. They comprise some 13 units, some of which are now extinct but known through limited wordlists collected in the 1970s. Further details — and a map — concerning this language group may be found in this volume (Boyeldieu, Kastenholz, Kleinewillinghöfer \& Lionnet 2020). ${ }^{1}$

The aim of the present paper is to provide insight into the forms, organization, and behaviour of the personal pronouns of the Bua

${ }^{1}$ For a more extensive presentation, see also Boyeldieu, Kastenholz, Kleinewillinghöfer \& Lionnet 2018 (henceforth BKKL 2018). 
languages. However, the uneven nature - in both quantity and quality of the sources available will make the goal necessarily modest: not all languages are documented for our purpose and the transcription of some data happens to be rather approximate (as a general rule I am following the orthographic choices made by the authors).

Out of the 13 units below, only the eight languages in bold will be considered here (endonyms are in italics; extinct languages are indicated in square brackets):

- Lua or Nielim, Niellim

$-[$ Cini $]$

- Tun or Tunya, Tounia

- $[$ Perim $]$

- $[$ Los or Noy $]$

- Ba or Bua, Boua

- Kawãwãy or Korom (?)

- Kulaal or Iro Gula, Goula d'Iro

- Kulaale or Eyle, Fanya, Fanian

- Zan Gula, Goula de Zan (Mэre)

- Bon Gula, Goula de Bon (Eeni)

- Bolgo (including Terew, Bolgo, Bormo)

- Koke

Personal systems will be presented and commented for each language before offering a short comparative overview in a concluding section.

Despite the above-mentioned limits of the documentation, the presentation and comparison of the systems prove to be useful, specifically with regards to the following most salient features:

1. Identity of persons:

- Inclusive/exclusive contrast for $1^{\text {st }}$ person plural

- Reflexive and/or Logophoric

2. Paradigms:

- Subject/Object as main contrast

- Tonal polarity of Subject/Object

- Possessive constructions 
It should be mentioned here, once and for all in this paper, that no language shows gender distinction in personal pronouns. In particular, $3^{\text {rd }}$ pers. sg. always has the full value of 'he/she/(it), him/her/(it), or his/her/(its)', even if the two (three) complementary meanings are not expressly mentioned in any given example.

\section{Lua}

Sources: (Boyeldieu 1985: 406-407, 409-413; unpubl. documentation; Testut 1978: 1-12; Vanderkooi 2000²).

Table 1

\section{Lua personal pronouns ${ }^{3}$}

\begin{tabular}{|c|c|c|c|c|}
\hline & Emphatic & Subject & $\begin{array}{l}\text { Object, } \\
\text { preposition- } \\
\text { governed, } \\
\text { possessive }\end{array}$ & Self \\
\hline $1 \mathrm{~s}$ & nìn & $\grave{n}$ & $n$ & măn \\
\hline $2 \mathrm{~s}$ & nìm & $\grave{m}$ & $\dot{m}$ & măm \\
\hline $3 \mathrm{~s}$ & nír & $\dot{r}$ & $\dot{r}$ & $\begin{array}{l}\text { măr (animate) } \\
\text { màr } \sim \text { mày } \sim \text { mànì (inanim.) }\end{array}$ \\
\hline LOGS & nì̀r & $\grave{r}$ & $\grave{r}$ & maìr (màr ?) \\
\hline $1 \mathrm{PE}$ & nìníi & $i$ & $i$ & măy \\
\hline 1PI & nì̀ & $\grave{i}$ & $\grave{i}$ & mày \\
\hline $2 \mathrm{P}$ & níi & $i$ & $i$ & măy \\
\hline $3 \mathrm{P}$ & náá & $a^{\prime}$ & $a^{\prime}$ & mă màná (anim. \& inanim.) \\
\hline LOGP & nà $\grave{a}^{3}$ & $\grave{a}$ & $\grave{a}$ & $?$ \\
\hline
\end{tabular}

${ }^{2}$ Despite its appealing title "Cohesion and Salience in Niellim Narrative: A look at discourse particles and participant reference", this MA thesis is of little use for our purpose given the fact that tones are usually not marked and the Logophoric forms are overlooked.

${ }^{3}$ The form is adapted from Testut nyà 'Réfléchi pluriel' (1978/3: 9) for which I postulate a long vowel by comparison with 3P.EMPH náá. 


\subsection{Persons}

In general, the $3^{\text {rd }}$ person pronouns (sg. or pl.) may refer to animates as well as to inanimate entities.

Lua has a contrast of 'exclusive/inclusive' $1^{\text {st }}$ pers. pl. pronouns (1 $\mathrm{PE} / 1 \mathrm{PI})$.

Logophoric pronouns are attested for both sg. and $\mathrm{pl}^{4}{ }^{4}$ Note that, in all paradigms, LOGS and LOGP differ from the corresponding $3^{\text {rd }}$ pers. pronouns by tone only.

As illustrated in (1), the Logophoric pronouns may refer to the reported speaker(s) within the sequence of reported speech:
(1) [...] málìm í jàà
[...] dán
páā jág
$t \bar{a}$ marabout DET say.IND leg=time some different then

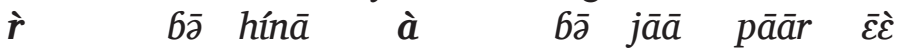
LOGS.SBJ FUT Come.vN LOGP.SBJ FUT word tell.vN eh! pàý kāỳ

INTERR what?

a. '.. the marabout said $[\ldots]$, another time $\boldsymbol{h e}$ would come [and] they would talk, isn't it?'

b. ' $\ldots$ the marabout said [...]: "another time, $\boldsymbol{I}$ will come [and] we will talk, isn't it?"' (Text: I, 63-64)

Both translations as indirect (a.) or direct (b.) speech are equally well-founded but the latter is usually more comfortable when a reference to the co-reported speaker is mentioned within the reported speech. Indeed this co-reported speaker is normally referred to, in Lua, not by a $3^{\text {rd }}$ pers. pronoun, as is more often the case, but by a $2^{\text {nd }}$ pers. pronoun, a situation that makes the logophoric discourse closer to a direct speech (in English terms). ${ }^{5}$ This principle is illustrated in (2):

${ }^{4}$ The logophoric plural forms were unfortunately ignored in Boyeldieu (1985: 406-407).

${ }^{5}$ About different types of reported speech and configurations of personal reference in reported speech in some African languages, see (von Roncador 1988: 289-293; Boyeldieu 2013: 27-34). 


\section{(2) $[. .$.$] le mál nè nìr \quad k \bar{a} y \quad$ gì á $\quad$ Pùrà and price REL LOGS.EMPH put.IND to 3P.PG pass.IND á súl ní á dùgà ná pàý nìm 3P.OBJ head COORD 3P.SBJ go_back.IND SUSP INTERR 2S.EMPH

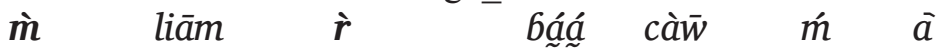

2s.SBJ match.IND LOGS.POsS child marry.VN DET INTERR [The chief is speaking to a young man who wants to marry his daughter.]

'[The chief said: “...] and the price that $\mathbf{I}$ set for them [i.e. the former suitors] went beyond them (lit. passed their head) and they went back, and you, you are able to marry my daughter?"' (Text: 413-25)

Logophorics, however, are not limited to the context of reported speech but, as in (3)-(4), they may also function as reflexive - or 'same referent' - possessives in the frame of one and the same clause. ${ }^{6}$ The term logophoric then has to be taken here in a wide sense. ${ }^{7}$

(3) $r$

$\begin{array}{lllllll}\dot{r} & t i & \dot{r} & \operatorname{lòg} & \grave{r} & \text { súl dāàn }\end{array}$

3s.SBJ stay.IND 3s.SBJ look_at.IND LOGS.Poss head middle

'He stayed (and) thought about (lit. looked at his own head's middle).' (Text: 409-10)

(4) $a$ wò bürr tì à

3P.SBJ PROG ask at LOGP.POSs middle thus

'They were asking among themselves (lit. in the middle of themselves) thus...' (Text: II, 5)

${ }^{6}$ Lua therefore proves to be a "mixed logophoric language" - as opposed to a "pure logophoric language" — in the sense of Culy (1994: 1056).

${ }^{7}$ If the principle of coreference undoubtedly works in such examples of spontaneous speech as (3) and (4), it is often not observed in elicited sentences where a 'same referent' interpretation is, however, indisputable, e.g. $\dot{r}$ dì $\dot{r}$ jí (not ... $\grave{r}$ jî) $\{3$ s.SBJ / open_wide.IND / 3s.Poss / eye $\}$ (not $\{\ldots /$ Logs.Poss / eye $\}$ ) 'S/he is opening her/his (own) eyes wide.' 


\subsection{Paradigms}

Lua has a limited contrast between subject pronouns and pronouns that function as object, preposition-governed adjuncts, and possessive. The two paradigms are identical except for $1 \mathrm{~s}$ and $2 \mathrm{~s}$ that have opposite tones (Low for subject $v s$. High for object-possessive).

\subsubsection{Subject}

As in (5), subject pronouns are preposed to the verb (tonally marked as either indicative or injunctive) or, in case of complex forms, to one of the three aspect markers wò 'Progressive', $6 \bar{\partial}$ 'Future', or ká 'Obligative' (Boyeldieu 1985: 353-355).

(5) a. $\dot{r} \quad s \grave{r}$

3s.SBJ go.IND

'S/he goes.'

b. $\dot{r} \quad s i$

3s.SBJ go.INJ

'S/he should go, s/he has to go.'

c. $\dot{r} \quad$ wò sāál

3s.SBJ PROG go.vN

'S/he is going.'

\subsubsection{Object}

Object pronouns are postposed to the verb as in (6)-(7), but they precede the verbal noun form in case of complex verbal forms (8). Note that in (7), both objects, directly postposed to kà 'make' and $n \bar{a}$ 'give', do not refer to a patient, but to a benefactive.

(6) - [...] ná ní măy làg jāā nèn nă then 2P.EMPH 2P.SELF look_at.INJ word DEM INTERR bááa păy nìr nā jāā dúnā child INTERR LOGS.EMPH with word life[Ar.] 
lǒl $\quad \bar{a}$

NEG INTERR

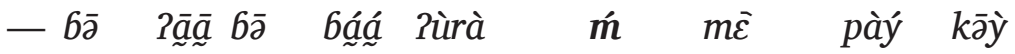
QUOT yes QUOT child exceed.IND 2s.oBJ but[Fr.] INTERR what? [the chief is speaking to his people, commenting on the wisdom of the young suitor]

'- [The chief said: “...] then, you (pl.), yourselves, look at these words! didn't the child defeat me with his words of wisdom [lit. of life]?

— [the people said:] yes! the child defeated you, didn't he?"' (Text: 419-54/55)

(7) Gááa tābā tī Pùūl sì sì tén wà̀n kà child fall.IND at way go.IND go.IND find.IND chief make.IND

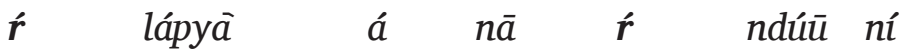
3s.oBJ greeting[Ar.] 3P.SBJ give.IND 3s.oBJ water COORD $\dot{r} \quad n i ̀$

3s.SBJ drink.IND

'The child took the road, he went, he went, he found the chief and greeted him [lit. made greetings (to) him].

They gave him water and he drank.' (Text: 411-16/17)

(8) $[\ldots]$ wò nè tà bà

person REL then FUT 2s.oBJ escort.vN COORD

tèní $\quad[\ldots]$

not be.IND

'[...] there is nobody [...] who will escort you [...].' (Text: 413-33)

\subsubsection{Preposition-governed}

As for preposition-governed pronouns, they follow the preposition they are governed by as shown in (9):

(9) $\begin{array}{lllllllll}a & d \bar{d} & \text { gì } & \dot{r} & \text { kuàl } & n i ́ & \dot{r} & t i ̄\end{array}$

3P.SBJ throw.IND to 3s.PG mat COORD 3s.SBJ stay.IND

'They gave him a mat and he had a rest.' (Text: 411-18) 


\subsubsection{Possessive}

Possessive pronouns precede the head noun. As illustrated in (10), this is the only possible construction with a personal modifier (there are more if the modifier is a noun). In particular Lua does not make any distinction corresponding to the so-called 'alienable/ inalienable' contrast.
(10) a. $\grave{n}$
líi
1s.Poss house
'my house'
c. á
líi
3P.POSS house
'their house'
e. $n$
súl
1s.Poss head
'my head'
b. $\dot{n}$
làg
1s.Poss house.PL
'my houses'
d. $\boldsymbol{a}$
lāg
3P.POSS house.PL
'their houses'
3P.poss head
'their head'
f. á súl

\subsubsection{Emphatic}

In comparison with the preceding paradigms, Emphatic pronouns formally result from the prefixation of an irregular sequence $n-$. Although the choice of these 'heavy' or 'long' forms is not always clear, they obviously may function as topic, as in (2) nìm $\{2$ s.EMPH $\}$ 'you!'. But sometimes also, the emphatic nature of the pronoun seems to make it the preferred form for a logophoric: see for instance nìr \{LOGS.EMPH instead of a simple subject form in (2), or instead of a simple object form in (6).

\subsubsection{Self}

This last paradigm is not well known. The self pronouns, normally preceded by an emphatic pronoun (e.g. nír măr 's/he him/herself') or by a noun (lág mă lág màná 'the houses themselves') are chiefly made up of pronouns similar to the object, preposition-governed and possessive ones but preceded by an element mà- that is unidentified. Yet this principle does not explain all forms, especially the $3^{\text {rd }}$ person pronouns, some of which may refer specifically to inanimate objects. 


\section{Tun}

Sources: (Palayer 1975), [L2 document] (unpubl.).

Table 2

Tun personal pronouns

\begin{tabular}{|c|c|c|c|c|}
\hline & \begin{tabular}{|l} 
Subject \\
(Perfective)
\end{tabular} & \begin{tabular}{|l|}
$\begin{array}{l}\text { Subject } \\
\text { (Intentional)? }\end{array}$ \\
\end{tabular} & Object & Possessive \\
\hline $1 \mathrm{~s}$ & ле̄, ла̄, (ла̄á, ná) & nà & nè & nè \\
\hline $2 \mathrm{~s}$ & mā, (māá, má) & $?$ & mò & mà \\
\hline $3 \mathrm{~s}$ & $\grave{i}$ & $?$ & $d \bar{o}$ & $d \bar{\partial}$ \\
\hline $1 \mathrm{PE}$ & bā, (bāá, bá) & $?$ & bù & bà \\
\hline 1PI & $j i$ & $?$ & $j i$ & $j \grave{i}$ \\
\hline $2 \mathrm{P}$ & $\bar{\imath}$ & $?$ & $\grave{\imath}$ & $i$ \\
\hline $3 \mathrm{P}$ & mà & $?$ & $\bar{e}$ & $\bar{e}$ \\
\hline
\end{tabular}

\subsection{Persons}

Tun has an 'exclusive/inclusive' contrast for the $1^{\text {st }}$ pers. pl. forms.

No logophoric has been recorded but the existence of such a pronoun cannot be excluded since the data are limited and no text is available.

\subsection{Paradigms}

The subject (intentional) paradigm is uncertain.

Object and Possessive should probably be considered only one paradigm. They only display some vocalic variants $(0 / a$ for $2 \mathrm{~s}-3 \mathrm{~s}$ and $u / \partial$ forl $\mathrm{PE}$ ) that are probably explained by their position regarding the governing lexical unit - following the verb (object) but preceding the noun (possessive) - and a difference of resulting syllable stress.

If we except $1 \mathrm{PI}$ and $3 \mathrm{P}$, all the other persons show a tonal contrast of Mid tone for Subject - at least Perfective - vs. Low tone for Object / Possessive. ${ }^{8}$

${ }^{8}$ It should be noted that basically no High tone appears in the Tun personal pronouns, a possible clue for a former two-tone system (see converging data in BKKL 2018: 100) 
Examples (11) to (13) illustrate the position of subject (Perfective), object, and possessive pronouns respectively. As in Lua, there is only one construction for what could be, elsewhere, 'alienable' and 'inalienable possession'.
(11) a. $\boldsymbol{n} \overline{\boldsymbol{e}}$
tūú
1S.SBJ eat.PF
b. mà
tūú
'I have eaten.'
3P.SBJ eat.PF
'They have eaten.'
(12) a. ì
sōy jè
b. $\grave{i}$
sōy
$\overline{\boldsymbol{e}}$
3s.SBJ hit.PF 1s.OBJ
'S/he has hit me.'
$3 \mathrm{~s} . \mathrm{SBJ}$ hit.PF
'S/he has hit them.'
c. $i$
dōō jè
3s.SBJ touch.PF 1s.oBJ
'S/he has touched me.'
(13)
a.jè sáy
1s.poss house
'my house'
d. $i$
dōō
3P.OBJ
1s.Poss head
'my head'
c. nè sī

$\begin{array}{lll}\grave{\imath} & d \bar{o} \bar{o} & \overline{\boldsymbol{e}} \\ \text { 3s.SBJ } & \text { touch.PF } & \text { 3P.oBJ } \\ \text { 'S/he has touched them.' }\end{array}$
b. $\overline{\boldsymbol{e}}$
sáy
3P.Poss house
'their house'
d. $\overline{\boldsymbol{e}} \quad s \bar{\imath}$
3P.Poss head
'their head'

\section{Ba}

Sources: (Boyeldieu, pers. doc.; Lionnet, pers. doc.).

Table 3

Ba personal pronouns

\begin{tabular}{|c|c|c|c|c|}
\hline & Independent & Subject & Object & Possessive \\
\hline $1 \mathrm{~s}$ & $6 \check{i}$ & $\grave{e}$ & é & é \\
\hline $2 \mathrm{~s}$ & 6ìm, 6òm & $\grave{m}$ & $\dot{m}$ & $m$ \\
\hline $3 \mathrm{~s}$ & 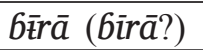 & $\bar{a}, \bar{a} r \bar{a}$ & $\bar{a}, r \bar{a}$ & $\bar{a}, r \bar{a}, \bar{a} r \bar{a}$ \\
\hline LOGS & $6 \grave{\imath}$ & $6 \grave{i}$ & 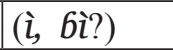 & $\grave{i}, 6 i$ \\
\hline $1 \mathrm{P}$ & 6òw & ù (ò?) & ú (ó?) & ú (ó?) \\
\hline $2 \mathrm{P}$ & bèy & $\grave{\imath}(\grave{e} ?)$ & $i$ (é?) & $i$ (é?) \\
\hline $3 \mathrm{P}$ & Gè6é & bé & bé & bé \\
\hline LOGP & 6òw & bòw & $(\grave{u}, 6 o ̀ w ?)$ & ù, fòw \\
\hline
\end{tabular}




\subsection{Persons}

According to both sources, there seems to be no 'exclusive/inclusive' contrast in the $1^{\text {st }}$ pers. pl.

Singular and plural logophoric pronouns are present in all paradigms. As in Lua, they operate within the reported speech $(14 \mathrm{a}-\mathrm{b})$ but also, like reflexive pronouns, within one and the same clause $(15 \mathrm{a}-\mathrm{b})$ :
(14) a. $\bar{a}$
$\operatorname{lig} g \bar{a}$
$6 \bar{a}$
$\bar{a} \quad l a ̀$
wūn
3s.SBJ say.IND QUOT 3s.SBJ see.IND thing
'S/he ${ }_{i}$ said that $\mathbf{s} / \mathbf{h e}_{\mathbf{j}}$ saw something.'
b. $\bar{a}$
$\operatorname{le} g \bar{a}$
$6 \bar{a}$
bì
là
$w \bar{u} n$
3s.SBJ say.IND QUOT LOGS.SBJ see.IND thing
'S/he ${ }_{i}$ said that $\mathbf{s} / \mathbf{h e}_{\mathrm{i}}$ saw something.'
a. $\bar{a}$
sòw
$\bar{a}$
sìlí
3s.SBJ catch.IND 3s.poss head
'S/he ${ }_{\mathrm{i}}$ took his/her ${ }_{\mathrm{j}}$ head.'
b. $\bar{a}$ sòw ì ( bì) silí
3s.SBJ catch.IND LOGS.Poss head
'S/he ${ }_{i}$ took his/her ${ }_{\mathrm{i}}$ head.'
(15)

\subsection{Paradigms}

$\mathrm{Ba}$ has four paradigms of personal pronouns - Independent, Subject, Object, and Possessive - but the last two would probably show as one paradigm with the help of more complete data. Variations between the vowels $u \sim o(1 \mathrm{P})$ and $i \sim e(2 \mathrm{P})$ reflect inconsistency between sources (Boyeldieu $\sim$ Lionnet).

Here again there is a tonal contrast of Low tone for Subject vs High tone for Object/Possessive in 1s, 2s, 1P, and 2P.

Let us now briefly comment on and illustrate the behaviour of these different paradigms.

\subsubsection{Independent}

The independent pronouns formally result from the prefixation of a $6 \mathrm{~V}$ type sequence to the forms displayed in the other paradigms. The main 
function that has been noted is as topic. Example (16) illustrates this use with cases of topicalization of a subject pronoun that may be doubled (or not), at least in the case of 1s.SBJ and 3P.SBJ.
(16) a. $6 \check{\boldsymbol{\imath}}$
(è) là
b. Gèbé
(6é) là
1S.INDP 1s.SBJ see.IND
3P.INDP 3P.SBJ see.IND
'Me, (I) saw.'
c. ... $6 \bar{a}$ bòw là
QUOT LOGP.INDP see.IND
'... (say) that themselves saw.'

\subsubsection{Subject}

The Subject pronoun precedes the verb.
(17) a. $\grave{e}$
là $(g) \quad w \bar{u} n$
b. Gé
là $(g) \quad w \bar{u} n$
1s.SBJ see.IND thing
'I saw something.'
3P.SBJ see.IND thing
'They saw something.'
c. ... $6 \bar{a} \quad$ bòw là $(g) \quad w \bar{n} n$
QUOT LOGP.SBJ /see.IND thing
'... (say) that themselves saw something.'

\subsubsection{Object}

The Object pronoun follows the verb (examples with a logophoric object have not been checked as such):
(18) a. $\bar{a}$
làg
é
b. $\bar{a}$
làg $\quad$ bé
3s.SBJ see.IND 1s.obJ
'S/he saw me.'
3s.SBJ see.IND 3P.oBJ
'S/he saw them.'
c. ... $\quad 6 \bar{a} \quad \bar{a} \quad$ làg ù QUOT 3s.SBJ see.IND LOGP.OBJ
'... (say) that s/he saw themselves.'
d. $\bar{a}$ $n \bar{e}$
é
3s.SBJ chase.IND 1s.oBJ
'S/he chased me.'
e. $\bar{a}$
$n \bar{e}$
6é
f. ... $6 \bar{a} \quad \bar{a} \quad n \bar{e}$
QUOT 3S.SBJ chase.IND LOGP.OBJ
'... (say) that $\mathrm{s} / \mathrm{he}$ chased themselves.'




\subsubsection{Possessive}

The Possessive pronoun precedes the head noun. This is the only pattern and $\mathrm{Ba}$ does not make any contrast of an 'alienable/inalienable' relation.
(19) a. é
min
b. 6é
$\min$
1s.Poss thing.PL
'my things'
3P.POss thing.PL
c. $\grave{u}$
min
〜 6òw
'their things'
LOGP.POSS thing.PL
'their own things'
LOGP.POSS thing.PL
d. é
1s.poss head
'my head'
f. $\grave{u}$
LOGP.POSs head
'their own head'
e. Gé silli
3P.Poss head
'their head'

\section{Kulaal}

Sources: (Pairault 1966; 1969; unpubl. documentation).

Table 4

Kulaal personal pronouns (incomplete, labels mine)

\begin{tabular}{|c|c|c|c|c|c|c|c|}
\hline & Independent & Subject & Object & \begin{tabular}{|l|} 
Preposed \\
possessive
\end{tabular} & $\begin{array}{l}\text { Postposed } \\
\text { possessive }\end{array}$ & Self & Focalized \\
\hline $1 \mathrm{~s}$ & $?$ & ñó, $n-$ & $\tilde{n} \grave{o}$ & $\tilde{n} \grave{o ̀, ~}(n ?)$ & ñò-n & ñòmmé & 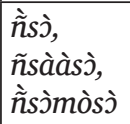 \\
\hline $2 \mathrm{~s}$ & $?$ & mó, m- & mò & mò & $m \grave{o ̀ n}$ & mòmmé & mòs ̀̀ \\
\hline $3 \mathrm{~s}$ & 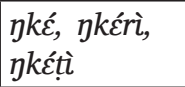 & $a ́$ & $\grave{\varepsilon}, n \grave{e}$ & $\grave{a}$ & $p \grave{\varepsilon}(\grave{\varepsilon})$ & $?$ & \begin{tabular}{|l|}
$\tilde{n}$ ńsó, \\
$\tilde{n}$ ñ́mòsò
\end{tabular} \\
\hline LOGS & $\varepsilon \eta k \varepsilon r l$ & $\varepsilon ́ n$ & $\grave{\varepsilon n}$ & $?$ & Ènn-è & & $?$ \\
\hline $1 \mathrm{PE}$ & $\begin{array}{l}\text { púmmèrì, } \\
\text { púmmèyùùrì }\end{array}$ & pú & & $?$ & pìn & púmè & $?$ \\
\hline 1PI & $\begin{array}{l}\text { émmèrì, } \\
\text { émmèyùùrì }\end{array}$ & én & èn & $?$ & èn (*ènn-è) & $?$ & $?$ \\
\hline
\end{tabular}


End of Table 4

\begin{tabular}{|c|c|c|c|c|c|c|c|}
\hline & Independent & Subject & Object & \begin{tabular}{|l|} 
Preposed \\
possessive
\end{tabular} & \begin{tabular}{|l|} 
Postposed \\
possessive
\end{tabular} & Self & Focalized \\
\hline 1PI & $\begin{array}{l}\text { émmèrì, } \\
\text { émmèyùùrì }\end{array}$ & én & èn & $?$ & èn ("ènn-è) & $?$ & $?$ \\
\hline $2 \mathrm{P}$ & $\begin{array}{l}\text { ímmèrì, } \\
\text { ímmèyùừì }\end{array}$ & $i$ & $i$ & $i$ & ìn (ì-n?) & $?$ & $?$ \\
\hline $3 \mathrm{P}$ & $\begin{array}{l}\text { mmérì, } \\
\text { mméyùùrì }\end{array}$ & $u$ ú é & $\begin{array}{l}\grave{U}, \\
(m) m e ̀\end{array}$ & $\grave{U}$ & & $?$ & $?$ \\
\hline LOGP & ? & món & mònnè & ? & $\begin{array}{l}\text { món, mónnè } \\
\text { (mónn-è?) }\end{array}$ & $?$ & $?$ \\
\hline
\end{tabular}

Giving a picture of the Kulaal pronouns is a challenge since no systematic paradigm is available and information has to be gathered from different parts of Pairault's works. Moreover, most Kulaal texts lack glosses or word-by-word translations and the interpretation of sentences based on their global translation happens to be a difficult task. Glosses are mine throughout this section.

\subsection{Persons}

Kulaal has an exclusive/inclusive contrast for the $1^{\text {st }}$ person plural pronouns (1 PE/1PI).

It has also both sg. and pl. pronoun forms that Claude Pairault defines as reflexive 3rd pers. pronouns of the "indirect style" (Pairault 1969: 262,270 ), and that clearly represent logophoric forms (LOGS/LOGP). While there are clear examples of use in reported speech, as in (20)-(21), the logophoric apparently does not work as reflexive within one clause:

(20) á kól

á wíl téć-à pè

“én

tín lóśpil,

3s come_back 3s tell father-3s QUOT LOGS.SBJ find sacred_stone lóópil mèț̀ á sj̀̀ èn tak."

sacred-stone this[?] 3s follow LOGS.OBJ [COMPLETION?]

'As he came back, he told his father: "I found a sacred stone. This stone is following me." ['De retour, il dit à son père : " J'ai trouvé une pierre sacrée. Cette pierre me suit. »'] (Pairault 1969: 162-163/ line 10-4-11) 
(21) Ú-pè á hừ̀pá-pè

3P-QUOT 3s wash-[COMPLETED?]

à món illáá-nè.

then LOGP.SBJ show-3s

'They say: "Wash all of us. Then we will show you."' ['Ils disent : «Lave-nous tous. Ensuite nous t'indiquerons. "'] (lit. they say that he has to wash themselves all of themselves; then themselves will show him.) (Pairault 1969: 242-243/line 12-2-59)

\subsection{Paradigms}

\subsubsection{Independent, Self and Focalized}

Some of the above formally complex paradigms are incomplete and not explained. The plural independent forms probably include the noun yờ $(t)$

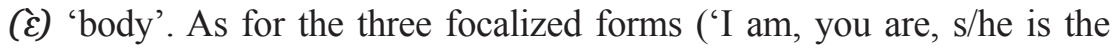
one who...'), they contain a s̀̀ element that could represent a former, frozen agreement determiner for nouns denoting 'humans' (see BKKL 2018: 77-78).

\subsubsection{Subject}

Subject pronouns, which precede the verb (e.g. ñó pààți 'I do'), may undergo some variations when themselves preceded by one of the two aspect markers lì 'Progressive' (e.g. lì ñò pààtì 'I am doing') and lá 'Near future' (Pairault 1969: 90):

Table 5

Kulaal Subject pronouns and variants in the context of aspect markers lì and lá

\begin{tabular}{|c|c|c|c|}
\hline & Subject & + Progressive lì & + Near future lá \\
\hline $1 \mathrm{~s}$ & ñó, $n-$ & lì ñò, lì $n$ - & lá ñó \\
\hline $2 \mathrm{~s}$ & mó, m- & lì mò, lì m- & lá mó \\
\hline $3 \mathrm{~s}$ & $a ́$ & lì̀ & láá \\
\hline LOGS & $\varepsilon ́ n$ & $?$ & $?$ \\
\hline $1 \mathrm{PE}$ & $p u ́$ & lì-pù & lá-pú \\
\hline
\end{tabular}


End of Table 5

\begin{tabular}{|l|l|l|l|}
\hline & Subject & + Progressive lì & + Near future lá \\
\hline $1 \mathrm{PI}$ & én & lèn & lá-én \\
\hline 2P & í & lì̀ & lá-í \\
\hline 3P & Ú, é & lù & lá-ú \\
\hline LOGP & món & lì mòn & $?$ \\
\hline
\end{tabular}

5.2.3. Object

Object pronouns follow the verb, see (20)-(21) above.

\subsubsection{Possessive}

Possessive pronouns may be either preposed or postposed to the head noun. In the latter case, the possessive itself is suffixed with a connective element that is mainly realized as $-n$ (after vowel) or $-e$ (after consonant). The semantics of this contrast is unclear but, as suggested by (22), it has apparently nothing to do with an 'alienable/inalienable' opposition. ${ }^{9}$

(22) a. ñò-húl

1s-head

'my head'

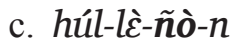

head-DET-1s-CONN

'my head' b. à-húl

3s-head

'his/her head'

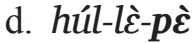

head-DET-3s.CONN

'his/her head"

Other examples are (23) for a preposed construction, as well as (24)-(25) for postposed constructions:

(23) à íl-è àmpúk

3s name-DET Ampuk

'Its name (is) Ampuk [a type of beer].' (Pairault 1969: 96-97/line 7-3-13)

9 The hyphenation principles adopted by Claude Pairault are not always consistent and should not be given too much significance. 


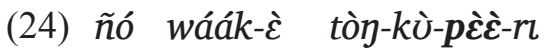

$1 \mathrm{~s}$ keep-3s house-DET-3s.CONN-in

'I keep it in her [referring to a woman] house.' (Pairault 1969: 114-115/line 8-77)

$\begin{array}{lllll}\text { (25) wj̀sà } & \text { pèè } & \text { lì-n-țápé } & \text { tòráà-kù } & \text { c̀n-nè } \\ \text { somebody } & \text { QUOT } & \text { PROG-[1s.SBJ!?]-want } & \text { cubit-DET } & \text { LOGS-CONN }\end{array}$ '[...] whoever wants [it] can deliver one's full potential (lit. wants one's cubit).' ['[...] quiconque le veut peut donner sa mesure.'] (Pairault 1969: 126-127/line 8-211) ${ }^{10}$

Finally the two nouns èè 'mother' and téć 'father' display complex and irregular possessive paradigms that I mention here for the record only:

Table 6

Kulaal Possessive paradigms of èè 'mother' and téć 'father'

\begin{tabular}{|c|c|c|c|c|}
\hline & 'mother' & 'mothers' & 'father' & 'fathers' \\
\hline $1 \mathrm{~s}$ & ñò’èèkípč̀̀ & ñò'èèkípċ̀-m-pò & $n$ t́té à à & ǹ-t́ćz à-m-pò \\
\hline $2 \mathrm{~s}$ & èèkùm & mò'èèkípc̀̀-m-pù & téć ùm & mò-tćć à-m-pò \\
\hline $3 \mathrm{~s}$ & 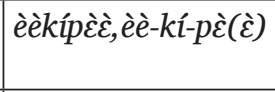 & a’èèkíṗ̀̀-m-pù & téć à & 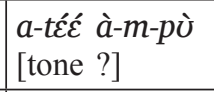 \\
\hline LOGS & è̀̀kì-ñ & $?$ & $t t^{\prime} \dot{\varepsilon}-\tilde{n}$ & $?$ \\
\hline $1 \mathrm{PE}$ & pừèèkípč̀̀ (1PE?) & pư'èèkípč̀̀-m-pù (1PE?) & pù téć à & 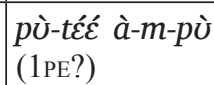 \\
\hline 1PI & $?$ & ìn'èèkípì̀̀-m-pù (1PI?) & ? & 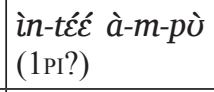 \\
\hline $2 \mathrm{P}$ & i’èèkípèc̀ & 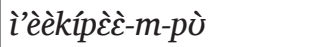 & ì tóć & 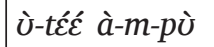 \\
\hline $3 \mathrm{P}$ & Ù’èèkípc̀̀̀ & u’èèkípè̀े-m-pù & ù téć à & ù téékúm \\
\hline LOGP & ? & ? & ? & ? \\
\hline
\end{tabular}

${ }^{10}$ lì- $n$ might in fact represent not only the progressive form of the $1^{\text {st }}$ pers. sg. ( $\{$ PROG-1S.SBJ $\})$ but also that of the Logophoric singular (\{PROG-LOGS.SBJ $\})$, which is not illustrated in Table 5 above. 
5.2.5. Tonal contrast in Subject vs. Object \& Possessive

Whereas all subject forms have High tone, most pronouns in the object and the two possessive paradigms have Low tone. The only one exception is LOGP among the postposed possessives. (Note also that High tones of subject pronouns are systematically converted to Low in presence of the Progressive marker lì, see Table 5 above.)

\section{Kulaale}

Source: (Lionnet 2018; pers. com.).

Lionnet (pers. com.) completes Table 7 as follows:

- There are two series of subject pronouns: one used with indicative verb forms, the other with subjunctive verb forms.

- Although object and possessive pronouns are formally identical, the former follow the verb predicate while the latter precede the head noun.

- The emphatic possessive pronouns are postnominal, and are likely historically derived from a connective construction CONN + PRONOUN '(the one) of me/you...'. The connective is $k \hat{\varepsilon} \sim k \hat{\varepsilon}$ in the singular, tú $\sim \hat{v}$ in the plural.

- There is no inclusive/exclusive distinction in $1 \mathrm{P}$.

- The logophoric pronouns do not seem to be used outside of reported speech, e.g. to express reflexive possession (e.g. mămmàt ${ }_{i}$ wé $\grave{\varepsilon} m \grave{\varepsilon} \dot{\varepsilon}_{i / j} /$ "ì $\boldsymbol{\eta}_{i}$ kímá 'Mahamat ${ }_{\mathrm{i}}$ came with his ${ }_{\mathrm{i} j \mathrm{j}}$ knife'). This will need to be further investigated.

- 1s subject $\hat{N}$ undergoes place assimilation with following consonant: $\left[\dot{n}, \mathfrak{n}, \grave{\eta}, m^{\prime}\right]$.

- All pronouns are [-ATR] except 2P, which is always [+ATR].

- Tonally, all independent pronouns are LH; indicative subject pronouns are all $\mathrm{H}$ except $1 \mathrm{P} \grave{j}$; subjunctive subject pronouns are all L; Object/possessive pronouns are all L, except 3s $\tilde{\varepsilon}$; Emphatic possessive pronouns are all HLH. 


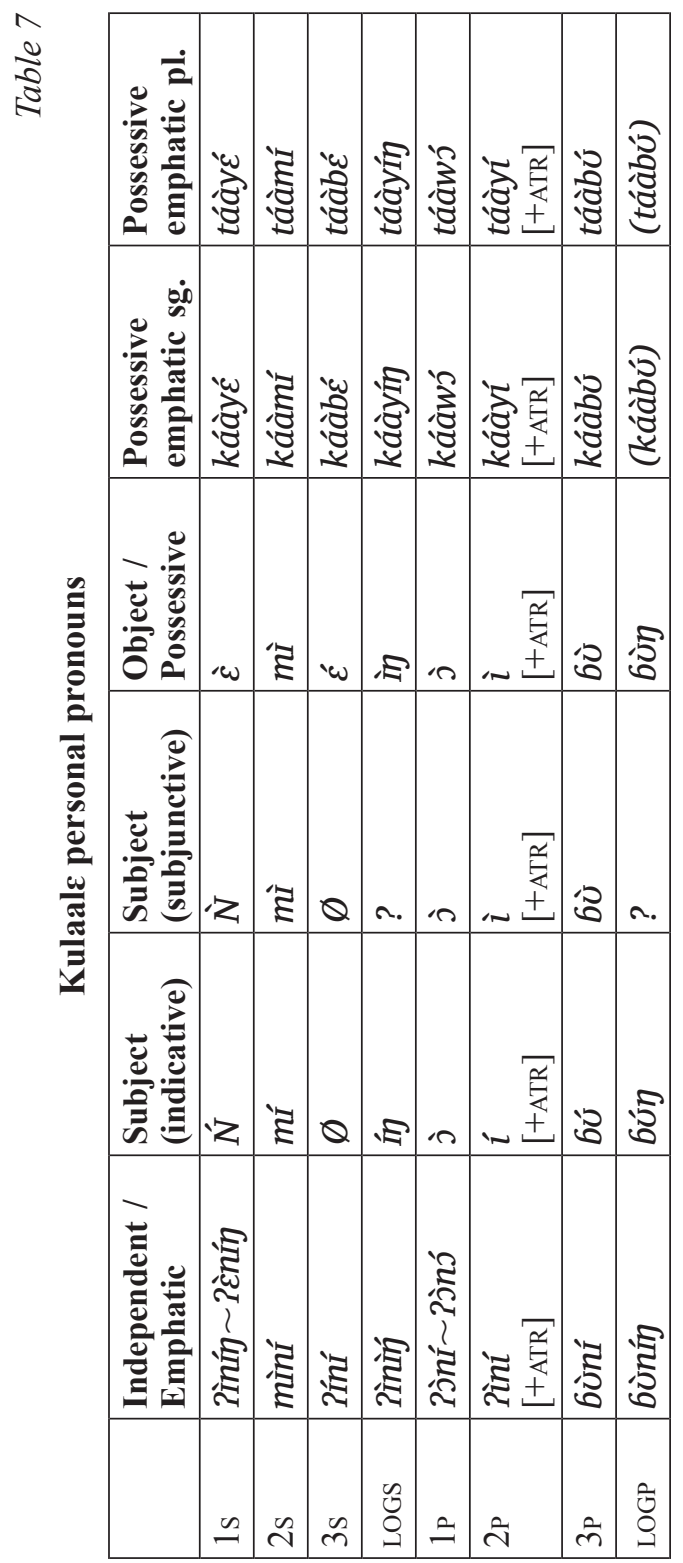




\section{Zan Gula ${ }^{(1)}$}

Source: (Ahmat \& Weiss 2010).

It happens that different sources concerning the same language or what is supposed to be the same language - do not match properly. Such cases may namely result from dialectal divergence, heterogeneous descriptive approaches, or complementarity in the features selected by the authors. In such a situation it would be both difficult and risky to combine the data into one and the same presentation. Rather, I will treat these cases as independent sources in different sections, that is $\S 7 \mathrm{Zan} \mathrm{Gula}^{(1)}$ and $\S 8 \mathrm{Zan} \mathrm{Gula}^{(2)}$, as well as $\S 10 \mathrm{Bolgo}^{(1)}$, $11 \mathrm{Bolgo}^{(2)}$, and $\S 12 \mathrm{Bolgo}^{(3)}$.

Table 8

\section{Zan Gula ${ }^{(1)}$ personal pronouns}

\begin{tabular}{|c|c|c|c|c|c|}
\hline & Independent & Subject & \begin{tabular}{|l} 
Direct \\
object
\end{tabular} & \begin{tabular}{|l|} 
Indirect \\
object
\end{tabular} & \begin{tabular}{|l|} 
Possessive \\
\end{tabular} \\
\hline $1 \mathrm{~s}$ & no & nì / a ñì & $-n, n e$ & nee & nì \\
\hline $2 s$ & mo & $m i$ & $-m, m o$ & moo & $m i$ \\
\hline $3 \mathrm{~s}$ & lô & iì & $-l, l e$ & lee & ní \\
\hline LOGS (?) & & (ka) le? & & & \\
\hline $1 \mathrm{PE}$ & $b u$ / bô & $b i$ & $b u$ & buu & $b i$ \\
\hline 1PI & wô & úú & $w U$ & $w U U$ & ú \\
\hline $2 \mathrm{P}$ & Ye / îyo & $i$ & $y i$ & $y i i$ & $i$ \\
\hline $3 \mathrm{P}$ & $b u$ / uwo & $\grave{u}$ & $b u$ / wu & buu & $\grave{u}$ \\
\hline
\end{tabular}

Data and comments concerning Zan Gula are extremely cursory. I do not know whether the uppercase $Y$ in Independent 2P is relevant and I do not understand the value of the boldfaced variants in the Independent and Indirect Object paradigms. Tones are usually not marked. 


\subsection{Persons}

There is clearly an 'exclusive/inclusive' contrast in the $1^{\text {st }}$ pers. pl. pronouns.

Relying on example (26a-b), the authors speculate on the existence of a Logophoric pronoun $\mathrm{ka}$ le or le (?).

(26) a. Mûusa sôm baa a kîro

Moussa say CONN he come

'Moussa says that he (i.e. somebody else) will come.'

b. Mûusa sôm baa kale kîro

Moussa say CONN he come

'Moussa says that he (i.e. Moussa) will come.'

If so, the same form could perhaps be identified in a further example with intentional value (27) (?):

(27) Hassan à yôw le rôo fara

Hassan he go [himself?] sow sorghum

'Hassan is going to sow sorghum.' [lit. H. is going, [intending] that himself will sow sorghum (?)]

The authors also speculate on the existence of a 'serial' (i.e. 'sequential'?) 3s pronoun (with verbs in the past). This form is not mentioned in Table 8 above.

(28) Alî lî saale mi oki faade mi yôw kedde

Ali eat paste he[?] go_out enclosure he[?] go hunting

'Ali ate the paste, then he got out of the house, and he went hunting.'

\subsection{Paradigms}

\subsubsection{Subject}

The subject pronoun, which is dependent on the TAM markers (no illustration), precedes the verb:

(29) a ni ôle noso -so

I see thing unknown

'I see something.' 


\section{(30) $\boldsymbol{i}$ ñe ñeme Nûura -lee he give meat Nuura to her 'He gives meat to Nuura.'}

\subsubsection{Direct \& Indirect object}

The direct (31a-b) or indirect (32) object pronoun follows the verb. Note that the $-C V$ and $-C$ variants of the singular direct object are complementarily suffixed to consonant-final and vowel-final verbs:

(31) a. $i$ sôni- $\boldsymbol{n}$

he pricks-me

'He pricks me.'

b. $i$ fom-no

he loves-me

'He loves me.'

(32) $i$ ne -lee ñeme

he give to him meat

'He gives him meat.'

\subsubsection{Possessive}

There is only one syntactic structure for modifying the noun with a possessive pronoun and there is no contrast such as 'alienable/ inalienable possession':

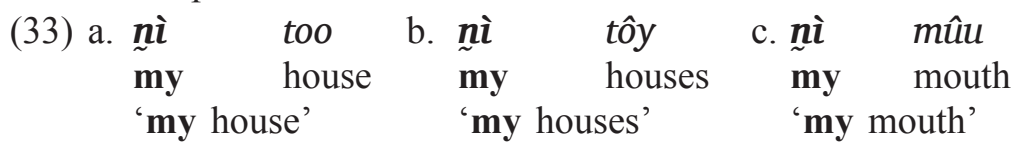

\section{Zan Gula ${ }^{(2)}$}

Source: (Rendinger 1949: 184-190).

Although Rendinger (1949), an older source on Zan Gula, is of limited reliability, I have to mention here the fact that the author makes a clear distinction between two possessive constructions. The first one 
Table 9

Zan Gula ${ }^{(2)}$ personal pronouns

\begin{tabular}{|l|l|l|}
\hline & Personal pronouns & Emphatic \\
\hline $1 \mathrm{~s}$ & n'e, n'o, n' & n'o n'on'o, n'e nò \\
\hline $2 \mathrm{~s}$ & mó, am, $m$ & mó nò \\
\hline $3 \mathrm{~s}$ & o, n'i, mó n'i, sa, lò gé & n'i nò, mó n'i nò \\
\hline $1 \mathrm{p}$ & buoni & $?$ \\
\hline $2 \mathrm{p}$ & yémi (< bié mi?), yemigo & $?$ \\
\hline $3 \mathrm{p}$ & sau & $?$ \\
\hline
\end{tabular}

is illustrated in (34): as in Zan Gula ${ }^{(1)}$, the Possessive pronoun is prefixed to the head noun, without any specific marker (glosses are mine):
(34) a. n'a-ha
1s.Poss-wife
'my wife'
d. n'i-gin'é
1s.POss-teeth
'my teeth'
b. n'a-hālé
1s.Poss-neck
'my neck'
e. n'u-dullé
1s.Poss-knee
'my knee'
c. n'é-félé
1s.Poss-nose
'my nose'

In the second construction, a different form of the possessive pronoun follows the head noun, which is itself followed by an invariable connective bé ("particule indiquant la possession"):

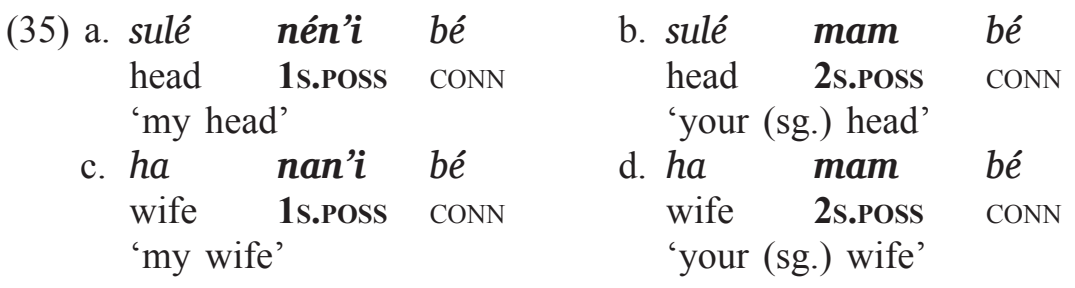

Nothing is said concerning the respective value of each construction. Since both (34)-(35) illustrate kinship or body part terms only, it is likely that no distinction of the 'alienable/inalienable' type is involved. 


\section{Bon Gula}

Sources: (Roberts 2004; 2010).

Table 10

Bon Gula personal pronouns

\begin{tabular}{|c|c|c|c|c|c|}
\hline & Independent & $\begin{array}{l}\text { Subject } \\
\text { of Past }\end{array}$ & $\begin{array}{l}\text { Subject } \\
\text { of Present }\end{array}$ & $\begin{array}{l}\text { Relative } \\
\text { Subject? }\end{array}$ & $\begin{array}{l}\text { Object } \\
\text { (suffixed } \\
\text { to -V / -C) } \\
\end{array}$ \\
\hline $1 \mathrm{~s}$ & noojo & ni & nim & an & $-\underset{\sim}{n} /-\underbrace{}_{\sim}$ \\
\hline $2 \mathrm{~s}$ & moojo & $m i$ & $\min$ & $a m$ & $-(u) m /-m o$ \\
\hline $3 \mathrm{~s}$ & yeejo & --- [i?] & in & $a$ & $-y /-y e$ \\
\hline $1 \mathrm{PE}$ & beebe & be & bey & $b$ & $-b e$ \\
\hline 1PI & e-eni & $e$ VB- $(e) n$ & $e \eta \mathrm{VB}-(e) n$ & $e$ VB-(e)n & eni \\
\hline $2 \mathrm{P}$ & îibe & $\hat{\imath}$ & $\hat{\imath} \eta$ & ay & $\hat{\imath}$ \\
\hline $3 \mathrm{P}$ & uube & $u$ & un & $a w$ & $-u /-w u$ \\
\hline
\end{tabular}

\begin{tabular}{|l|l|l|}
\hline & Possessive & $\begin{array}{l}\text { 'Possessive pronouns' } \\
\text { (singular / plural possessed object) }\end{array}$ \\
\hline $1 \mathrm{~s}$ & ni & no no / ne ne \\
\hline $2 \mathrm{~s}$ & $\mathrm{mi}$ & mo no / me ne \\
\hline $3 \mathrm{~s}$ & yi & ye no / ye ne \\
\hline $1 \mathrm{pe}$ & $\mathrm{ba}$ & be no / be ne \\
\hline $1 \mathrm{pi}$ & $a$ & eni no / eni ne \\
\hline $2 \mathrm{p}$ & $\hat{\imath}$ & $\hat{\imath}$ no / îne \\
\hline $3 \mathrm{p}$ & $u$ & u no / u ne \\
\hline
\end{tabular}

Bon Gula sources consist of two SIL working papers that still contain some unsolved analyses and inconsistent transcriptions. They are nevertheless worthwhile in the absence of other documents. The main source used here is (Roberts 2010), unless otherwise specified. Note that glosses are mine throughout this section. 


\subsection{Persons}

Bon Gula has an 'exclusive/inclusive' contrast for the $1^{\text {st }}$ pers. pl. pronouns. On the other hand, no logophoric pronoun — or specific pronoun of indirect speech - is mentioned.

\subsection{Paradigms}

\subsubsection{Independent}

When compared with the object pronouns that are suffixed to final consonant verbs $(-C)$, independent forms are clearly suffixed with -jo in the singular and with -be in the plural. The only exception is $1 \mathrm{PI}$ e-eni, which should perhaps be compared with the endonym Eeni 'Bon Gula language' (Roberts 2004: eeni).

As suggested by no 'me' in example (36) below, there might exist 'short' forms of this paradigm.

\subsubsection{Subject(s)}

The contrast 'Subject of Past' vs. 'Subject of Present' is not clear and apparently not supported by the rare examples available, which only illustrate 1s ' $I$ ' in (36) or the discontinuous 1PI 'we (excl.)' in (37)-(38):

(36) ño ni yerki haw kîr 1s.INDP[?] 1s.SBJ.PAST[!?] listen_to dog bark 'Me, I listen to the barking dog.'
e-eni,
$\boldsymbol{e}$
bôô-n
bala
1 PI.INDP 1PI.SBJ.PAST[!?]... tie-...1PI.SBJ goat
'We (incl.), we (incl.) tie the goat.'

\section{(38) e-eni, \\ e \\ um-en \\ dokil-lo}

1 PI.INDP 1PI.SBJ.PAST... kill-...1PI.SBJ leopard-DEF

'We are the ones who (we, incl.) have killed the leopard.'

More complete paradigms may be found in Roberts (2004), e.g. (39) and (40) (hyphenation and glosses are mine). Note that, again, despite the translation, the preposed forms are often the ones belonging to the 'Subject of Past' paradigm. Also, there is only one $1^{\text {st }}$ pers. pl. 
here, probably the $1^{\text {st }} \mathrm{pl}$. 'exclusive', but with forms ( $\left.p a, p a \eta\right)$ that differ from Table 10 above (be, bey). In addition, the form Ì-wòy ' $\mathrm{S} /$ he goes out' in (40) suggests that the 'Subject of Past' 3s is $i$ - rather than <--->, as indicated in Table 10 above (based on Roberts 2010).

$\begin{array}{llll} & \text { kul-in } & \text { drink-INF } & \text { 'to drink' } \\ \text { 1s } & \text { nu-kuli } & \text { 1s.PAST[??]-drink } & \text { 'I drink.' }\end{array}$

2s min-kuli 2s.PREs[?]-drink 'You (sg.) drink.'

3s ìn-kùlì 3s.PREs[?]-drink 'S/he drinks.'

1P pày-kùlì 1P.PRes[?]-drink 'We drink.'

2P ín-kùlì 2P.PREs[?]-drink 'You (pl.) drink.'

3P úm-gùlì 3P.PREs[?]-drink 'They drink.'

(40) wวy-en go_out-INF 'to go out'

1s nU-woy 1s.PAST[!?]-go_out 'I go out.'

2s mo-woy 2s.Past[!?]-go_out 'You (sg.) go out.'

3s ì-wòy 3s.Past[!?]-go_out 'S/he goes out.'

1P pà-wòy 1P.Past[!?]-go_out 'We go out.'

2P Í-wòy 2P.PAST[!?]-go_out 'You (pl.) go out.'

3P Ú-wòy 3P.PAST[!?]-go_out 'They go out.'

Finally, the existence of a "Relative Subject" paradigm is suggested by Roberts (2010) on the evidence of limited examples like (41)-(42):

(41) kûm an hellenu

flour 1s.ReL buy

'the flour that I have bought'

Amate in haykî lal a hêllo

Amat 3S.PRESENT[?] think millet 3s.REL burn

'Amat(, he?) is thinking of the millet that (it) has burnt.'

\subsubsection{Object}

Object pronouns are suffixed to the verb, except for $1 \mathrm{PI}$ and $2 \mathrm{P}$, which are said to be postposed (and not hyphenated). Singular object pronouns have complementary forms $-\mathrm{C}$ or $-\mathrm{CV}$ according to the final segment - 
vowel or consonant - of the verb. Note that the independent pronoun may also work as object, as happens for 3P in (43a).

a. 1s Ali dû- $\boldsymbol{n}$ Ali / surpass-1s.oBJ 'Ali surpassed me.'

2s Ali dû-m Ali / surpass-2s.oBJ 'Ali surpassed you.'

3s Ali dû-y Ali / surpass-3s.oBJ 'Ali surpassed him/her.'

1 PE Ali dû-be Ali / surpass-1PE.oBJ 'Ali surpassed us (excl.).'

1 Pr Ali dû eni Ali / surpass / 1Pr.oBJ 'Ali surpassed us (incl.).'

2P Ali dû $\hat{\imath} \quad$ Ali / surpass / 2P.oBJ 'Ali surpassed you (pl.).'

3P Ali dû ûûbe Ali / surpass / 3P.INDP 'Ali surpassed them.'

b. 1s Ali hul-ño Ali / hit-1s.oBJ 'Ali hit me.'

2s Ali hul-mo Ali / hit-2s.oBJ 'Ali hit you.'

3s Ali hul-le Ali / hit-3s.oBJ 'Ali hit him/her.'

1PE Ali hul-be Ali / hit-1 PE.oBJ 'Ali hit us (excl.).'

1Pr Ali hul eni Ali / hit / 1Pr.obJ 'Ali hit us (incl.).'

2P Ali hul $\hat{\boldsymbol{\imath}} \quad$ Ali / hit / 2Р.оBJ 'Ali hit you (pl.).'

3P Ali hul-lu Ali / hit-3Р.овJ 'Ali hit them.'

\subsubsection{Possessive}

Possessive constructions are commented in Roberts (2010), who indicates only one syntactic pattern, in which the modifier precedes the head $(44 a-b)$. There is apparently no contrast between so-called 'alienable/inalienable' constructions. ${ }^{11}$

\begin{tabular}{|c|c|c|c|}
\hline a. & ni ton & 1s.Poss / house & 'my house' \\
\hline 1PI & $\boldsymbol{a}$ ton & 1PI.POss / house & 'our (incl.) house' \\
\hline 3P & $\boldsymbol{u}$ ton & 3P.poss / house & 'their house' \\
\hline 1 & ni tônde & 1s.Poss / house.PL & 'my houses' \\
\hline & a tonde & 1PI.POss / house.PL & 'our (incl.) house \\
\hline & tônde & 3P.poss / house.PL & 'their houses' \\
\hline
\end{tabular}

${ }^{11}$ One can wonder, however, about the precise semantics of a phrase like 'my heads' in (44b). 


$\begin{array}{llll}\text { b. 1s } & \text { ni hûl } & \text { 1s.Poss / head } & \text { 'my head' } \\ \text { 1PI } & \boldsymbol{a} \text { hûl } & \text { 1PI.Poss / head } & \text { 'our (incl.) head' } \\ \text { 3P } & \boldsymbol{u} h u \hat{l} & \text { 3P.Poss / head } & \text { 'their head' } \\ \text { 1s } & \text { ni hûn } & \text { 1s.Poss / head.PL } & \text { 'my heads' } \\ \text { 1PI } & \boldsymbol{a} \text { hûn } & \text { 1PI.Poss / head.PL } & \text { 'our (incl.) heads' } \\ \text { 3P } & \boldsymbol{u} \text { hûn } & \text { 3P.Poss / head.PL } & \text { 'their heads' }\end{array}$

\subsection{5. "Possessive pronouns"}

Finally Roberts (2010) identifies a double paradigm of "Pronoms possessifs (objet possédé au singulier) " and "Pronoms possessifs (objet possédé au pluriel)" (Possessive pronouns for singular/plural possessed object). The forms are not glossed, not translated and not illustrated. ${ }^{12}$ However, sg. no / pl. ne is identified elsewhere as a connective ("connectif") in such noun phrases as in (45) (glosses are still mine):
(45)
a. hûl bala no
head goat the_one_(of)
'the goat's head'
$\begin{array}{lll}\text { b. tu } & \text { maama } & \text { no } \\ \text { ear } & \text { child } & \text { the_one_(of) }\end{array}$
'the child's ear'
c. tû maama ne
ear.PL child the_one_(of).PL
'the child's ears'
d. ton mîne no
house child.PL the_one_(of)
'the children's house'
e. tônde maama ne
house.PL child the_one_(of).PL
'the child's houses'

The complex forms of the 'Possessive pronouns' paradigm would then read no no $\{1 \mathrm{~s} .[?] /$ the_one_(of) $\}$ 'the one of me, mine (sg.)' $/ \mathrm{pl}$.

${ }^{12}$ Remember, though, that the document was elaborated with and for Bon Gula speakers. 
ne ne \{1s.[?]/the_one_(of).PL $\}$ 'the ones of me, mine (pl.)', etc. However, the pronoun forms that precede the connective are not the possessive forms but are rather similar to the object forms that are suffixed/postposed to consonant-final verbs. So, the question remains open as to which personal pronouns are really involved here.

\section{Bolgo ${ }^{(1)}$}

Source: (Kastenholz 2017: 13-14, 20-21).

Table 11

Bolgo ${ }^{(1)}$ personal pronouns

\begin{tabular}{|l|l|l|l|}
\hline & Subject & Object & Possessive \\
\hline 1s & $n \bar{i}$ & $-V \bar{c}$ & $n \bar{\imath}$ \\
\hline 2s & $m \bar{a} m$ & $-V m$ & $?$ \\
\hline 3s & $j \bar{o}$ & $-V$ & $?$ \\
\hline 1P & $w \bar{a} w$ & $-V w$ & $?$ \\
\hline 2P & $y \bar{e}$ & $-V y$ & $?$ \\
\hline 3P & $6 \bar{a} b$ & $-V \bar{b}$ & $?$ \\
\hline
\end{tabular}

The variety of Bolgo described by Kastenholz (2017) is that spoken by people who call themselves Bólgò (glossonym Bólgònî), a subgroup of the so-called Bolgo 'Kubar'.

\subsection{Persons}

Bolgo has only one form of $1^{\text {st }}$ pers. pl. and no 'exclusive/inclusive' contrast. It also has no Logophoric pronoun.

\subsection{Paradigms}

\subsubsection{Subject}

The pronoun precedes the verb (46) or the auxiliary (47):

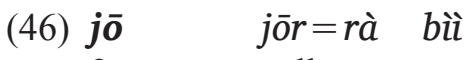

3SG.SBJ call=PF people

'He has called the people.' 


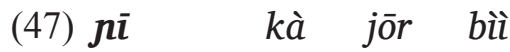

1SG.SBJ FUT call people

'I will call the people.'

\subsubsection{Object}

All the forms have been identified only in the context of a preceding (C) $V C$ verb. The behaviour of the personals is not documented after verbs of the $(C) V$ type.

Example (48) illustrates some vocalic variations of the clitic object according to the vocalic identity of the preceding lexical base (cp. $\bar{o} l$ 'see', él 'hit, strike'):
(48)
a. Brahim ól=um=nà
B. $\quad$ see $=\mathbf{2}$ s.OBJ $=$ PF
'Brahim has seen you (sg.).'
c. Brahim ól $=\boldsymbol{o}=$ rà
B. $\quad$ see $=\mathbf{3}$ s.OBJ $=\mathrm{PF}$
'Brahim has seen him.'
e. Brahim ól $=\boldsymbol{u} \boldsymbol{b}=r \grave{a}$
B. $\quad$ see $=\mathbf{3 P}$. . . $\mathbf{J}=\mathrm{PF}$
'Brahim has seen them.'
b. Brahim él=im=nà
B.
hit=2s.oBJ $=\mathrm{PF}$
'Brahim has hit you (sg.)'
d. Brahim él $=\boldsymbol{e}=$ rà
B. hit=3s.oBJ $=\mathrm{PF}$
'Brahim has hit him.'
f. Brahim él $=\mathbf{i} \boldsymbol{6}=$ rà
B. hit=3P.OBJ=PF
'Brahim has hit them.'

\subsubsection{Possessive}

The Possessive pronoun precedes the head noun (the only form documented, 1s.Poss, is the same as in the Subject paradigm):

(49) Hasib jī bín

H. 1sG.P brother.sG

'Hasib is my brother.'

\section{Bolgo ${ }^{(2)}$}

Source: (Tikka 2019: 93-99, 106-112, 114-115).

Tikka's work is based on the linguistic variety spoken by a subgroup known as Bolgo 'Dugag' (endonym Terew). Minor variations appear in comparison with Bolgo ${ }^{(1)}$ in the preceding section. 
Table 12

Bolgo $^{(2)}$ personal pronouns

\begin{tabular}{|c|c|c|c|c|}
\hline & Subject & Suffix & 'Possessive form' (?) & Possessive \\
\hline 1s & $\mu г \eta \sim \mu I$ & $-(V) \eta$ & abuy & nाy \\
\hline $2 \mathrm{~s}$ & $m a j \sim m a$ & $-(V) m$ & abum & maj \\
\hline $3 \mathrm{~s}$ & foj $\sim$ fo & $-a,-V,-\emptyset$ & $a b a$ & foj \\
\hline $1 \mathrm{P}$ & $w a j \sim w a$ & $-(V) w$ & abuw & waj \\
\hline $2 \mathrm{P}$ & $j e j \sim j e$ & $-(V) j$ & $a b i j$ & $j e j$ \\
\hline $3 \mathrm{P}$ & $b o j \sim b o$ & $-(V) b$ & $a b u b$ & $b o j$ \\
\hline
\end{tabular}

It has to be noted that the author's transcriptions strictly follow the IPA principles: in particular $f$ stands for [f] and $j$ for [j]. Unfortunately, and although the author is quite aware of the role of tone that she marks for lexical terms, she does not mark any tone on grammatical units, in particular not on pronouns.

\subsection{Persons}

Like Bolgo ${ }^{(1)}, \mathrm{Bolgo}^{(2)}$ has no 'exclusive/inclusive' contrast in the $1^{\text {st }}$ plural, and no specific Logophoric pronoun.

\subsection{Paradigms}

\subsubsection{Subject}

Subject pronouns all have a full and a short form. Full forms may be used as subject but speakers tend to favour the short variants (without final consonant), especially in the case of the $1^{\text {st }}$ Pers. sg. $M I$.

One and the same $3^{\text {rd }} \mathrm{sg}$. form is used for 'he', 'she', and 'it'.

\subsubsection{Suffix}

The actual realisation of the Suffixes results from complex rules involving the word shape of the preceding morpheme (final consonant or vowel) as well as its vocalic identity. The most diverse allomorphs including free variants - are found with the 3s Suffix. This is shown 
in (50), which displays but a selection of (surface?) realisations (Tikka 2019: 96-98):

(50) Stem > + 3s Suffix

\begin{tabular}{|c|c|c|}
\hline kāngí & [kayga] & 'to mix' \\
\hline t’̄̌rí & [toro] & 'to love' \\
\hline iulú & [tulo] & 'to hit with downward motion' \\
\hline $\bar{u} l g i$ & [hulgo] [hulga] & 'to stir' \\
\hline$\eta \bar{g}$ & {$[d \varepsilon \eta g \varepsilon] \sim[$ denga $]$} & 'to insult' \\
\hline$\hat{b} b \bar{a}$ & [hoba] & 'to hide' \\
\hline$l e \bar{e}$ & [nile] & 'to push' \\
\hline$t$ & {$\left[t_{\overline{0}}\right]$} & 'to take' \\
\hline & [tèè & 'to find' \\
\hline
\end{tabular}

Pronominal Suffixes are used for all types of object. However, except for the case of some common ditransitive verbs like nà 'give' (52) or tùmō 'send', indirect objects and benefactives are followed by the specific "dative marker' ${ }^{13} d I$ as in (53)-(54):
(51) foj ōló- $\boldsymbol{\eta}$
3 s.SBJ see-1s.oBJ
'He sees me.'
(52) boj nà- $\boldsymbol{\eta}$ nól
3P.SBJ give-1s.oBJ honey
'They are giving me some honey.'

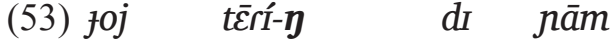
3s.SBJ buy-1s.oBJ DAT meat
'She buys meat for me.'

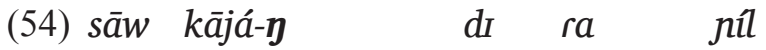
dog destroy-1s.oBJ DAT already broom
'The dog destroyed my broom.'

${ }^{13}$ This 'dative marker', as named by the author, is not illustrated after nouns but it is not clear whether its use is restricted to pronouns. It is not clear either whether it has to be analysed as a postposition or as an applicative marker somehow depending from the verb. In agreement with Sabine Littig (pers. comm.), I doubt we have to deal here with a case marker, a type of grammatical morpheme uncommon in Adamawa languages. 
Furthermore the same suffixes appear in a specific paradigm of 'possessive forms', based on an $a b$ - unit and used in such constructions as (55) (glosses are mine):
(55) a. (nI)
abuy
búsō
b. (maj) abum
búsō
(1s.SBJ) ?.1s.suff horse
'I have a horse.'
(1s.SBJ) ?.2S.SUFF horse
'You (sg.) have a horse.'

However, as stated by the author, these constructions as well as the 'possessive forms' they involve are not well understood:

"It seems that the pronominal suffixes have a dative function in these sentences, but it is unclear at this point whether the word to which they are attaching is a verb, a preposition, or something else." (Tikka 2019: 114-115).

\subsubsection{Possessive}

The full forms of the Subject paradigm - but not the short ones ${ }^{14}$ also work as possessives, which precede the head noun, e.g.:
(56) a. $\mathbf{n m}$
$b \bar{a} \bar{a}$
b. $m a j$
$b \bar{a} \bar{a}$
1s.Poss child
2s.poss child
'my child'
'your (sg.) child'

\section{Bolgo ${ }^{(3)}$}

Source: (Rendinger 1949: 179-184).

Table 13

Bolgo $^{(3)}$ personal pronouns

\begin{tabular}{|l|l|l|l|}
\hline & Personal pronouns & Possessive (a) & $\begin{array}{l}\text { Possessive (b) } \\
\text { and Emphatic }\end{array}$ \\
\hline 1s & $n^{\prime} e ́$, n'a, nãṇ & n'ẽn, nan n'ên & n'ena, n'eno \\
\hline 2s & may, ma, iéy (rare) & mām & mā no \\
\hline 3s & géya, giyo di, ma ri & oldio & diō no \\
\hline
\end{tabular}

14 Tikka (2019: 94, footn. 30), however, comments on some other forms possibly used as possessives. 
End of Table 13

\begin{tabular}{|c|c|c|c|}
\hline & Personal pronouns & Possessive (a) & \begin{tabular}{|l} 
Possessive (b) \\
and Emphatic
\end{tabular} \\
\hline $1 \mathrm{p}$ & way & wao, way & wa na \\
\hline $2 p$ & ié di & iéy & ié no \\
\hline $3 p$ & (bi si 'those people') & - & - \\
\hline
\end{tabular}

Although Rendinger's (1949) data have limited value (see $\S 8$ above), it is remarkable that the author, just as he did for Zan Gula ${ }^{(2)}$, identifies two distinct possessive constructions in Bolgo. ${ }^{15}$ In the first case the possessive pronoun precedes the head noun (glosses are mine):
a. n'eng
bīno
b. $m \bar{a} \overline{m o}$
bino
1s.Poss brother
2s.Poss brother
'my brother'
'your (sg.) brother'

In the second pattern, which is reminiscent of both Kulaal (\$5) and Zan $\mathrm{Gula}^{(2)}(\S 8)$, the possessive pronoun comes after the head noun and is itself followed by a connective $n 0^{16}$ as in (58):

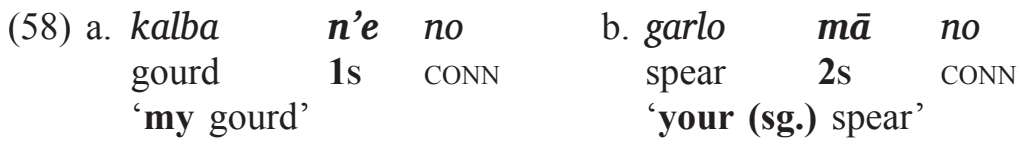

Finally, this latter pattern has an 'Emphatic' variant, characterised by an undefined element $g i$, inserted between the head noun and the possessive:

${ }^{15}$ Despite the limited quality of the source, I tend to trust the author on this point, as I did for Zan Gula. The fact that Bolgo ${ }^{(1)}$ and Bolgo ${ }^{(2)}$ have only one possessive construction may be explained by a difference of linguistic varieties: the author of $\mathrm{Bolgo}^{(3)}$ worked with people from Bolgo 'Dugag' and from Koke (Tikka 2019: 11). Another point that gives consistency to Général de Rendinger's analyses is simply the fact that similar syntactic constructions have been identified in Kulaal by Claude Pairault (see §5.2.4) and in Kulaale by Florian Lionnet (see §6).

${ }^{16}$ This resembles, of course, the connective sg. no / pl. ne of Bon Gula (see end of $\S 9$ above). 
(59)

$\begin{array}{llllllll}\text { a. bin } & \text { gi } & \text { n'e } & \text { na } & \text { b. garté } & \text { gi } & \text { diō } & \text { no } \\ \text { brother } & {[?]} & \mathbf{1 s} & \text { CONN } & \text { spear } & {[?]} & 2 \mathrm{~s} & \text { CONN } \\ \text { 'my brother' } & & & & \text { 'his spear' } & & \end{array}$

These are all the illustrations presented by the author. Examples (57) and (58) would not contradict the assumption that the distinction, whose semantics is not commented, is of an 'alienable/inalienable' nature ('brother' $v s$ 'gourd' and 'spear') but such a view is apparently not compatible with the lexical units involved in (59) ('brother' and 'spear').

\section{Comparative overview}

\subsection{Persons}

\subsection{1. $1^{\text {st }}$ plural 'exclusive/inclusie'}

The opposition of $1^{\text {st }}$ pers. pl. 'exclusive' vs. 'inclusive' is dominant: it is well attested in Lua, Tun, Kulaal, Zan Gula, and Bon Gula. It is apparently absent from $\mathrm{Ba}$, Kulaale, and Bolgo. Where it exists, the contrast $1 \mathrm{PE} v s$. $1 \mathrm{PI}$ is present in every paradigm, i.e. it goes through the whole pronominal system.

\subsubsection{Logophoric}

Logophoric pronouns are attested in Lua, Ba, Kulaal, Kulaale, and, questionably, Zan Gula. Because of the limits of the data currently available, their existence is not excluded in Tun. They most probably do not exist in Bon Gula and Bolgo. Logophorics, where they appear, are also well integrated in their system: they have singular and plural forms, and are attested in every paradigm.

In both Lua and $\mathrm{Ba}$, logophorics are used in the domain of reported speech (logophoricity stricto sensu) as well as in simple clauses (same referent). In Kulaal and Kulaale, however, they are seemingly limited to the former function. 


\subsection{Paradigms}

\subsubsection{Subject/object}

Although the number of distinct paradigms differs markedly from one source to another, there is a clear tendency for the whole group to contrast two major sets, namely Subject and Object, the Possessive pronouns often looking as a variant of the latter (Tun, Ba, Kulaal), if not being even identical (Lua, Kulaale). Objects, however, are usually postposed or suffixed to the verb, whereas possessives always are - or may be - preposed to the head noun.

In Lua, Tun, Ba, Kulaal, and Kulaale, the major division Subject/ Object is chiefly marked by tone contrasts. As shown in Table 14 below (grey cells), the segmental identity of pronouns is very similar in both paradigms, whereas tonal differences, if any, are as follows:

- Subject $=$ Low $v s$. Object $=$ High

- Lua: $1 \mathrm{~s}$ and $2 \mathrm{~s}$ only (other persons are identical)

- Ba: 1s, 2s, 1P, and 2P (other persons are identical or similar)

- Subject $=$ High $(\text { Tun Mid })^{17}$ vs. Object $=$ Low

- Tun: 1s, 2s, 1PE, and 2P (other persons have different forms)

- Kulaal: all persons (except 1PI, which is not known for Object)

- Kulaale (indicative subject only): $1 \mathrm{~s}, 2 \mathrm{~s}, 2 \mathrm{P}$, and $3 \mathrm{P}(1 \mathrm{P}$ is always L-toned, and 3s Subject/Object have different forms and same tone)

For the time being nothing can be said concerning Zan Gula, Bon Gula, and Bolgo, in which the tonal identity of personals is still missing.

\subsubsection{Possessive constructions}

All languages have a possessive construction that follows the pattern \{PRON.POSS / head_noun\}. For most of them this is the only way to specify a noun with a personal reference. But Kulaal, Kulaale, Zan $\mathrm{Gula}^{(2)}$, and Bolgo ${ }^{(3)}$ have an additional pattern \{head_noun / PRON.POss /

${ }^{17}$ Remember that only Low and Mid tones appear in the Tun personal pronouns (see above, §3, footn. 10). 
CONN\}, which can probably be explained as a former topicalized, appositive construction (lit. *'the house/head, the one of me' > 'my house/head'), at least if we assume that the connective marker was in fact a possessive (or associative) pronoun or substitute: 'the one (of)', similar to that which has been observed in Bon Gula (see end of $\S 9$ above). It is, however, not clear which semantic value is attached to either modifying pattern in the latter three languages. At least a correlation with the so-called 'alienable/ inalienable possession' seems to be excluded. ${ }^{18}$

\subsection{Summary and conclusions}

\subsubsection{Compared features}

The different features that have been mentioned with respect to persons or paradigms are summarized in Table 14 below.

Table 14

\section{Distribution of structural features}

\begin{tabular}{|c|c|c|c|c|c|c|c|c|}
\hline & Lua & Tun & $\mathbf{B a}$ & Kulaal & Kulaale & Z. Gula & B. Gula & Bolgo \\
\hline $\begin{array}{l}\text { 1p excl. } \\
\text { vs 1p incl. }\end{array}$ & + & + & - & + & - & + & + & - \\
\hline $\begin{array}{l}\text { Logophoric } \\
( \pm \text { refl.) }\end{array}$ & + & $?$ & + & + & + & $?$ & - & - \\
\hline $\begin{array}{l}\text { Object } \simeq \\
\text { Possessive }\end{array}$ & + & + & + & + & + & - & - & - \\
\hline $\begin{array}{l}\text { Tonal polarity } \\
\text { Subject/Object }\end{array}$ & + & + & + & + & + & $?$ & $?$ & $?$ \\
\hline $\begin{array}{l}\text { 'Preposed' } \\
\text { possessive }\end{array}$ & + & + & + & + & + & + & + & + \\
\hline $\begin{array}{l}\text { 'Postposed' } \\
\text { possessive }\end{array}$ & - & - & - & + & + & + & - & + \\
\hline
\end{tabular}

${ }^{18}$ The so-called 'possessive' (or associative) constructions definitely deserve a specific study that should take in account both pronominal and nominal modifiers. Unfortunately, such constructions as 'the one (of)' are not often documented in linguistic descriptions, and even less in grammatical sketches or limited surveys. 
The conclusions that can be drawn from such a chart are necessarily limited. It is possible, however, to emphasize the two following points:

i) the principle of a tonal polarity between Subject and Object paradigms (Table 17 below) is not a priori ruled out in Zan Gula, Bon Gula, and Bolgo, and could finally prove to be a distinctive structural feature of the historical system of personal pronouns common to all Bua languages,

ii) in the same historical perspective, the early existence of a 'possessive' construction following the pattern \{PRON.POSs / head_noun\}, which is present in all (described) present-day languages, is highly likely. This does not imply that it was necessarily the only one.

\subsubsection{Segmental forms}

Finally Table 16 below shows that several phonic recurrences indicated in grey cells - can be observed, from language to language, in both Subject and Object paradigms. These constant features are summarized in Table 15 in the form of pseudo-reconstructions. They concern only $1 \mathrm{~s}, 2 \mathrm{~s}, 1 \mathrm{PE}, 2 \mathrm{P}$, and $3 \mathrm{P}$. No attempt has been made to reconstruct the other persons, which display a more pronounced formal diversity. It is known that $3^{\text {rd }}$ pers. singular pronouns may be easily replaced by elements of varied origin (determiners, deictic pronouns, lexical units like 'person' or 'body'). Logophoric pronouns also may have various origins (emphatic, self, neuter or inanimate $3^{\text {rd }}$ pers. pronouns, definite or anaphoric marker) and they often show a marked diversity of forms and structures even across closely related languages (Boyeldieu 2013). As for the $1^{\text {st }}$ pers. pl. pronouns, the interpretation of the present data is uncertain, if not contradictory: obvious recurrences in $1 \mathrm{PE}$ suggest that the 'inclusive' $1 \mathrm{PI}$ forms, which are more varied, are also more recent. But if the assumption was right, we would also expect similar forms to $1 \mathrm{PE}{ }^{\circ} \mathrm{bu} / \mathrm{e} / \mathrm{i}$ in the languages $-\mathrm{Ba}$, Kulaale, and Bolgo - that have no 'exclusive/inclusive' contrast, which is not the case. 


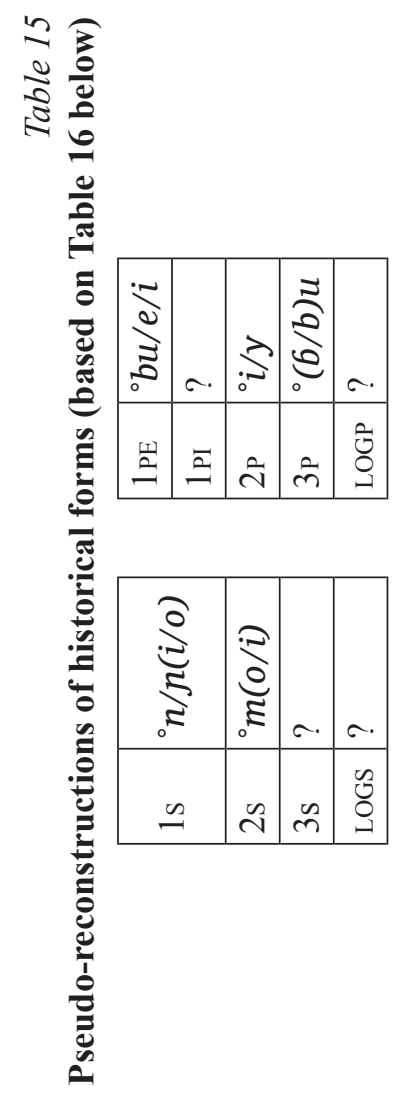

$\frac{0}{\frac{1}{2}}$

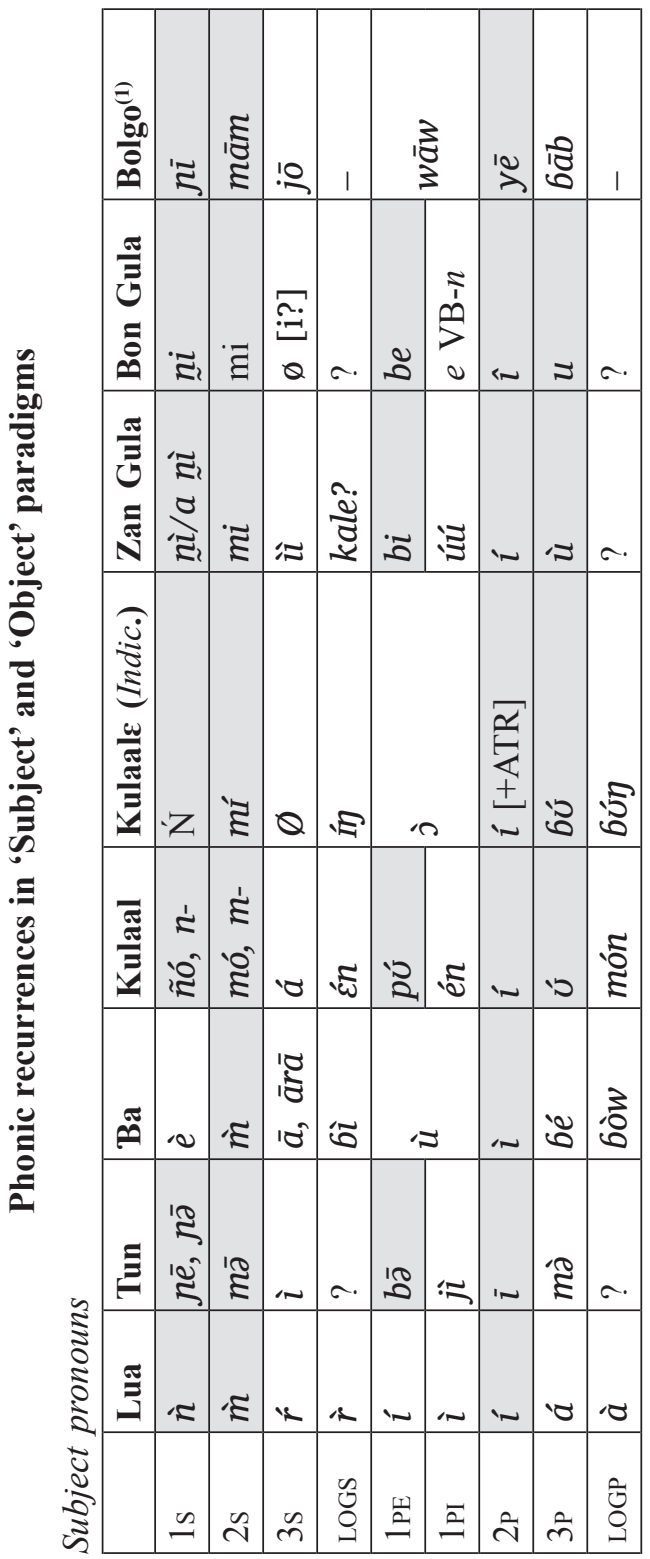




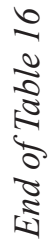

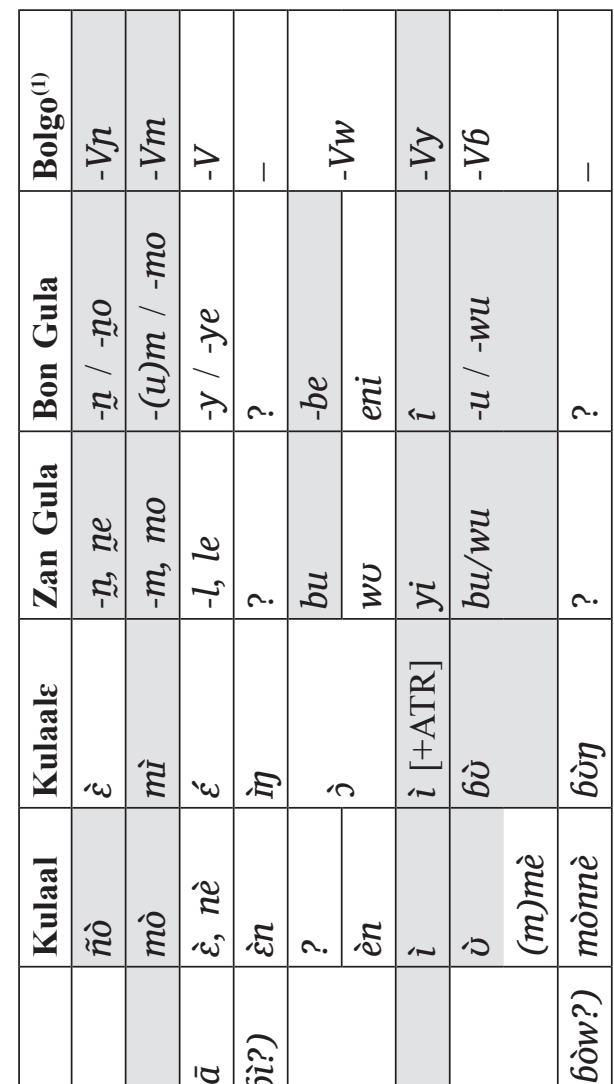

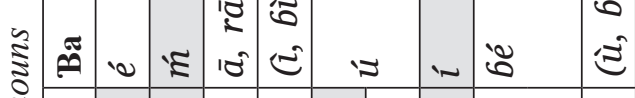

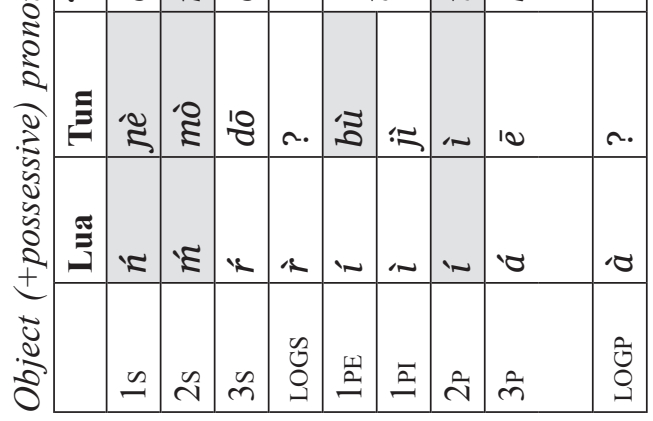

$\frac{\sqrt{0}}{\frac{\pi}{2}}$
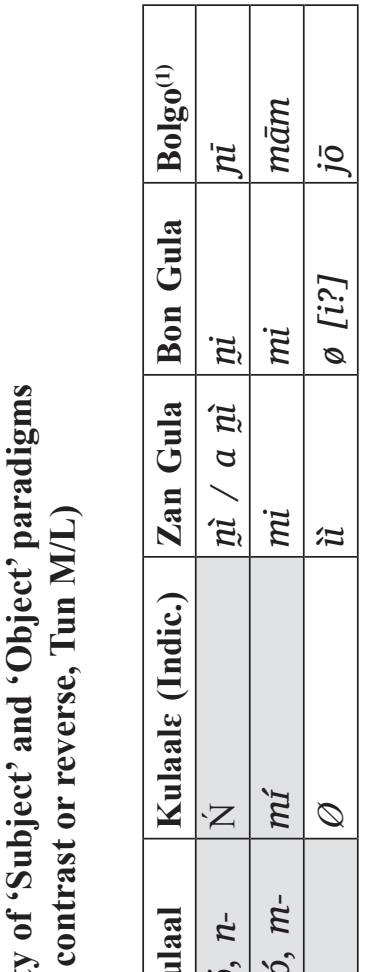

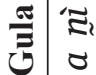

疍

芦

岂

次

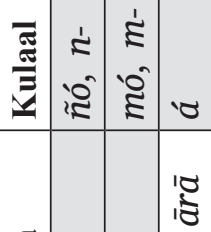

ค.

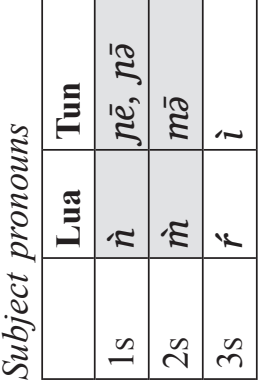




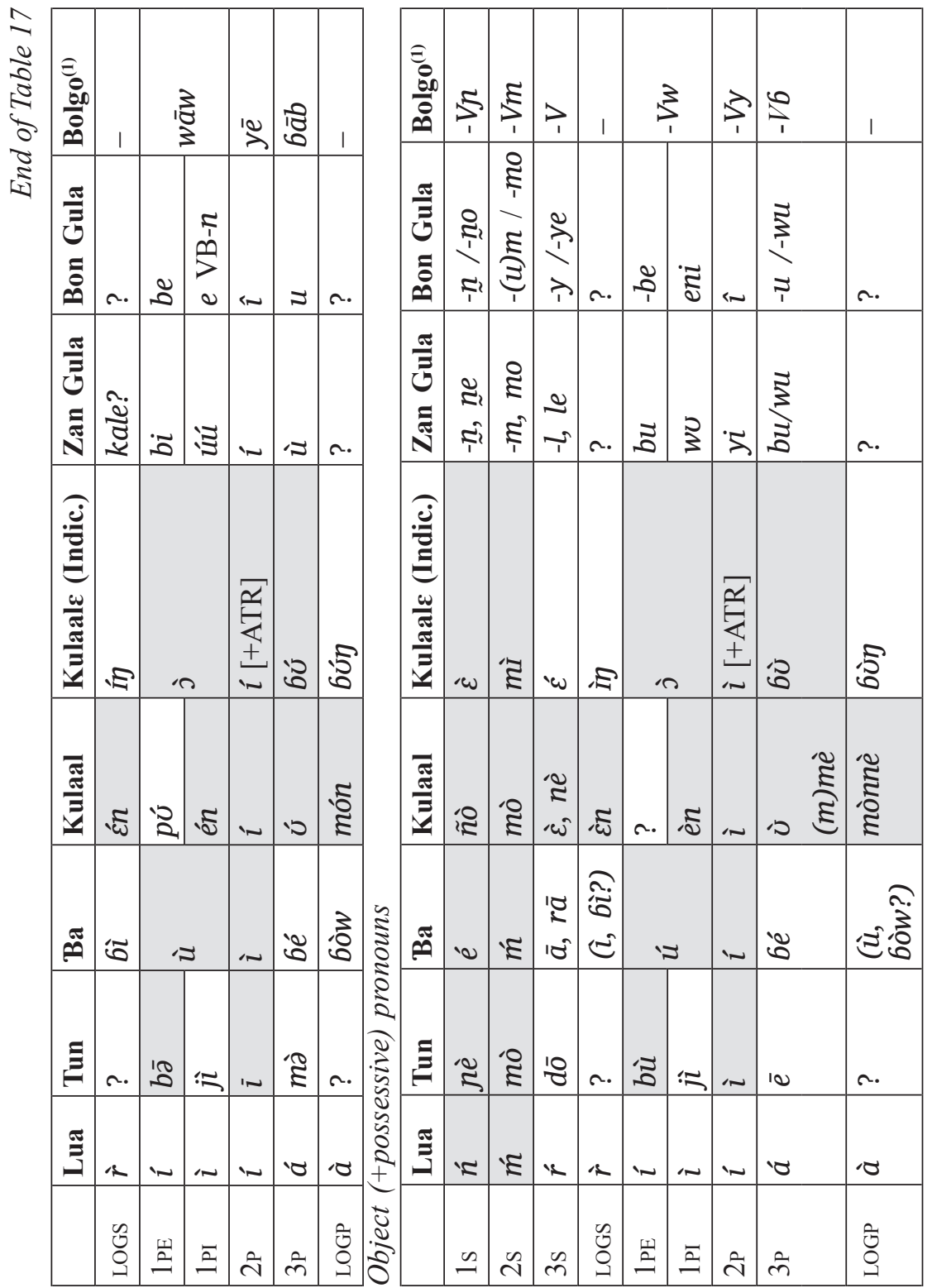




\section{Acknowledgements}

The present paper was conceived within the frame of an informal "Bua Comparative Group" involving, beside myself, Raimund Kastenholz, Ulrich Kleinewillinghöfer, and Florian Lionnet, whom I thank for their comments as well as for the data they made available to me. I express my gratitude to Jim Roberts who kindly circulated helpful SIL documents and working papers. I am also indebted to the editors and reviewers of this paper for their advices and suggestions. Finally, Florian Lionnet's careful checking of the English text was a valuable help.

\section{Abbreviations}

$1 \mathrm{PE}-1^{\text {st }}$ person plural exclusive

$1 \mathrm{PI}-1^{\text {st }}$ person plural inclusive

$1 \mathrm{~s}-1^{\text {st }}$ person singular

$2 \mathrm{P}-2^{\text {nd }}$ person plural

$2 \mathrm{~s}-2^{\text {nd }}$ person singular

$3 \mathrm{P}-3^{\text {rd }}$ person plural

$3 \mathrm{~s}-3^{\text {rd }}$ person singular

Ar. - Arabic

CONN - connective

COORD - coordinative

DAT - dative marker

DET - determinate, determiner

EMPH - emphatic

excl. - exclusive

Fr. - French

FUT - future

incl. - inclusive

IND - indicative

INDP - independent

INF - infinitive

INJ - injunctive
INTERR - interrogative

LOGP - logophoric plural

LOGS - logophoric singular

NEG - negative

OBJ - object

PAST - past

pers. - person

$\mathrm{PF}$ - perfective

$\mathrm{PG}$ - preposition-governed

pl., PL — plural

POss - possessive

PRES - present

PROG - progressive

PRON - pronoun

QUOT - quotative

REL - relative

SBJ - subject

sg., SG - singular

suFF - suffix

sUSP - suspensive

$\mathrm{vN}$ - verbal noun 


\section{References}

Ahmat, Oumar \& Doris Weiss. 2010. Esquisse grammaticale du more [Zan Gula] (avec des annotations par Silke Sauer). Mongo. Unpublished ms. (12 p.)

BKKL 2018: see Boyeldieu, Kastenholz, Kleinewillinghöfer \& Lionnet. 2018. Boyeldieu, Pascal. 1985. La langue lua («niellim») (Groupe Boua - MoyenChari, Tchad). Phonologie. Morphologie. Dérivation verbale. Paris: SELAF (Descriptions de Langues et Monographies Ethnolinguistiques 1). Boyeldieu, Pascal. 2013. Introduction. In Boyeldieu, Pascal. (éd.), Logophorique et discours rapporté en Afrique centrale, 9-36. Louvain-Paris: Peeters (Afrique et Langage 17.)

Boyeldieu, Pascal \& Kastenholz, Raimund \& Kleinewillinghöfer, Ulrich \& Lionnet, Florian. 2018. The Bua group languages (Chad, Adamawa 13): A comparative perspective. In Kramer, Raija \& Kießling, Roland (eds.), Current approaches to Adamawa and Gur languages, 53-126. Köln: Rüdiger Köppe. (Afrika und Übersee, Beiheft 34.)

Boyeldieu, Pascal \& Kastenholz, Raimund \& Kleinewillinghöfer, Ulrich \& Lionnet, Florian. 2020 The Bua group noun class system: Looking for a historical interpretation. Language in Africa 1(3). 181-215. (This issue.)

Culy, Christopher. 1994. Aspects of logophoric marking. Linguistics 32(6). 1055-1094.

Kastenholz, Raimund. 2017. La langue bolgo du Guéra (Tchad): notes de recherche et matériel lexical. (Working Papers of the Department of Anthropology and African Studies of the Johannes Gutenberg-University Mainz 172). http://www.ifeas.uni-mainz.de/Dateien/AP172.pdf

Lionnet, Florian. 2018. Minutes of Bua group meeting \#4 (Nov. 2018).

Mouchet, Jean. 1958. Contribution à l'étude du gula (Tchad). Bulletin de l'IFAN 20, série B (3-4). 593-611.

Pairault, Claude. 1966. Boum le Grand: village d'Iro. Paris: Institut d'Ethnologie.

Pairault, Claude. 1969. Documents du parler d'Iro, kùláál du Tchad. Paris: Klincksieck. (Langues et littératures de l'Afrique noire 5).

Palayer, Pierre. 1975. Esquisse phonologique de la langue tounia. In Boyeldieu, Pascal \& Palayer, Pierre (eds.). Les langues du groupe boua: Études phonologiques, 131-195. N'Djaména: INSH. (Études et documents tchadiens, Série C, Linguistique 2.) 
Rendinger, Général de. 1949. Contribution à l'étude des langues nègres du Centre Africain. Journal de la Société des Africanistes 19(2). 143-194.

Roberts, Jim. 2004. Notes on Bon Gula. [Mongo]. Ms.

Roberts, James, (avec l'assistance de Dewane, Hamdane \& Defalla, Issa). 2010. Esquisse de grammaire Bone Goula (Êeni). (Modifiée par Silke Sauer avec l'assistance de Adum Adef et Breme Outmane), DTL, Mongo. Ms.

Testut, Marie. 1978. Contes du pays Niellim. Ms. 3 vol. N'Djaména: CEFOD. Tikka, Katie Ann. 2019. Phonology and morphology of Bolgo. Grand Forks: University of North Dakota. (M.A. thesis.)

Vanderkooi, Diane R. 2000. Cohesion and Salience in Niellim Narrative: A look at discourse particles and participant reference. Arlington: University of Texas. (M.A. thesis.)

von Roncador, Manfred. 1988. Zwischen direkter und indirekter Rede. Nichtwörtliche direkte Rede, erlebte Rede, logophorische Konstruktionen und Verwandtes. Tübingen: Niemeyer. (Linguistische Arbeiten 192).

\section{Unpublished documentation}

Boyeldieu, Pascal: Lua, Ba

Lionnet, Florian (Princeton University): Ba, Kulaale

Pairault, Claude: Kulaal

Palayer, Pierre: Tun

Received 10.02.2020. Received in revised form 05.06.2020. Accepted 04.08.2020 